\title{
Saint Paul's Thorn in the Flesh: a Dermatological Weakness?
}

\section{ANTONIO MACAYA PASCUAL}

Dermatology Service, Hospital Universitari de Bellvitge, Barcelona and Universitat Abat Oliba, Barcelona amacayap@uao.es

ORCID: 0000-0003-4056-5260

\section{IGNACIO MANRESA LAMARCA}

Instituto de Estudios Teológicos San Ildefonso de Toledo, Universidad Eclesiástica San Dámaso igmanresa@gmail.com

ORCID: 0000-0003-0997-7697

\section{JAIME PIQUERO CASALS}

Dermik. Multidisciplinary Dermatology Clinic, Barcelona jaime.piquero@e-campus.uab.cat ORCID: 0000-0002-4481-5602

Abstract. Saint Paul's "thorn in the flesh" has been the subject of much controversy in medical, historical and religious literature. It was crucial for the development of Paul's theology and, therefore, its study is important for a better understanding of early Christianity. The purpose of this article is to review the available evidence on this issue, perform a historical and medical critical analysis and suggest plausible diagnosis that have not been previously published in scientific literature.

Our research on primary sources seem to indicate that in 41-42 AD Paul of Tarsus developed a clinical picture with a pain similar to that of a thorn injury and bad 
physical appearance. It could also have a chronic course with a limited number of relapses and few global. It could remind Job's illness and provoke humiliation in Paul and repulse in his audience.

Multiple diseases could explain some of these data, but fewer explain all of them. Though a definitive diagnosis cannot be achieved, we think that cutaneous disorders are the most obvious candidates for a humiliating and painful disease which, however, would permit long journeys during more than a decade. Disorders with cutaneous involvement like lupus erythematosus, dermatomyositis, urticaria/angioedema, herpes simplex leukocytoclastic vasculitis or nodular vasculitis should be added to other possibilities previously reported.

Keywords: thorn, flesh, Paul, skin, weakness, vasculitis, angio-edema, paniculitis.

\section{Introduction}

Paul wrote his second letter to the Christians in Corinth in AD 55-56 (Black 2012, 58). Possibly worried by the reports about questions on his authority in the local church, he dispatched Titus from Macedonia to Corinth with the letter.

His goal may not have been only to retrieve his leadership. Paul's own vindication rests on showing that he is a true Apostle with reasons of greatness, as visions and revelations of the Lord. But he also manifests that he will only boast on his weaknesses because of their instrumental power to get the grace of Christ.

In chapter 12 , he recalls a mystical experience " 14 years" before (AD 41-42) in "the third heaven" (2 Cor 12:2), or "paradise" (12:4), but just to explain, as a sharp contrast, that, in an imprecise moment after his mys-

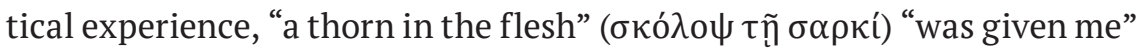

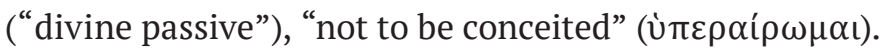

It is because of the repeated pleadings to be delivered from the thorn that Paul claimed to have received a message from Jesus: "suffices you my

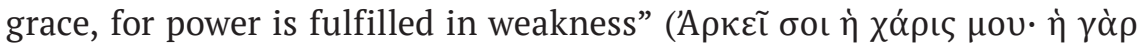

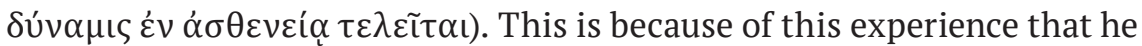
came to this conclusion: "I will not boast if not in the weaknesses" (12:5;

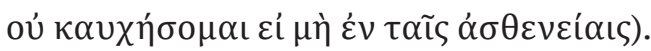

Hugues qualifies this statement as "the summit of the epistle" (Hugues 1962, 451). "This is the same theology he articulates throughout the 
letter (4:7-17), the theology he finds most clearly in the message of the cross (13:4)" (Keener 2005, 241). This message configured Paul's theology and we can say that the whole Christian message and had, therefore, a huge influence on western civilisation.

It is often repeated that the nature of this thorn cannot be known. However, Paul chose the thorn to explain one of his most important lessons. He could have chosen many other symbols or episodes occurred throughout his life, but he must have chosen this one for some special reason. It is clear that he thought that the thorn had a special explanatory power for christian life.

The purpose of this article is to perform a historical and medical analysis of the nature of the thorn, necessary for further theological implications that are only indirectly considered here.

\section{The nature of the thorn}

$\sigma \kappa o ́ \lambda o \psi$ is a rare term which denotes a "pointed stake" used in palisades, but it also describes a stake used for executions by impaling or by crucifixion (Kittel and Friedrich 1985, 947) (Danker and Bauer 2000).

Paul uses this word probably as a metaphor of a pain like the pain of a large thorn or a stake stuck in the flesh (Abernathy 2001). Park showed that $\sigma \kappa o ́ \lambda o \psi$ described a stake in some texts of Homer and others, used to impale the enemies. There is no consensus on if it can be used to refer to a cross (Park 1980) (Vincent's 2021). Jegher-Bucher maintains that Paul tried to communicate connotations of $\sigma \kappa o ́ \lambda$ o $\psi$ as a thorn (which would be significant for jewish audiences) and a stake (for hellenistic ones) (JegherBucher 1997).

Throughout history, some authors have proposed that the pain Paul alludes to could be suffering due to spiritual temptations, either carnal or due to his enemies.

Luther compared Paul's thorn with his own sufferings because of the value of the law (Luther 2011, 317). Several authors like Aquinas (Aquinas 1986, 472-474), and Cornelius a Lápide (à Lapide 1908, 187-189), thought that it could have been a spiritual trial because of carnal temptations. But 
this interpretation lays on the Vulgata's confuse rendering of the $\sigma \kappa o ́ \lambda о \psi$ $\tau \tilde{n} \sigma \alpha \rho \kappa i ́$ as stimulis carnis meae.

Carnis, as a genitive, qualifies the thorn, and this may have played a role in the understanding of the thorn as carnal temptations. But the greek and the underlying hebrew must be understood as a dative (Black 2012).

Secondly, to think about the thorn as carnal temptations seems inconsistent with Paul's claim about his gift of continence, and his recommendation to marry for those who don't have this gift (1 Cor 7:7) (Furnish 1984, 548). Thirdly, the persistence of a spiritual challenge like carnal temptations during many years and despite the petitions of the Apostle for the thorn to be removed seems unlikely.

The identification of the thorn with Paul's enemies lays on the use of the word $\sigma \kappa o ́ \lambda о \psi$ in the Old Testament. $\sigma \kappa o ́ \lambda o \psi$ is found three times in the LXX, describing God's punishment to Israel through his enemies (Num 33:55; Ez 28:24; Josh 23:13). This is the main argument for several authors to identify Paul's $\sigma \kappa o ́ \lambda o \psi$ with the affliction because of his opponents (Hubbard 2002) (Mullins 1957) or because of Israel's lack of faith or temptations of rejecting his ministry (McCant 1988). Abernathy (Abernathy 2001) takes the use in the LXX texts of $\sigma \kappa o ́ \lambda o \psi$ and $\beta 0 \lambda i \delta \varepsilon \varsigma$ referred to "eyes" and "sides" respectively, as a proof of the figurative use of the thorn by Paul.

Several reasons seem to be against the identification between the $\sigma \kappa o ́ \lambda o \psi$ and the enemies:

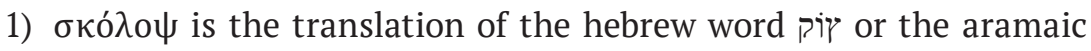
shpayaa. pir is a real thorn which shall grow on the cursed ground after the original sin (Gn 3:18), or on the idolatric altars of "the high places" (Hos 10:8). It can spread a fire (Ex 22:6) and can be used to tear the flesh (Jg 8:7). It represents enemies that are quickly consumed as burning thorns (Ps 118:12), that will be thrust away like thorns (2 Sam 23:6), that will come up on the land of the Lord's people (Is 32:13). It can also represent an unproductive harvest (Jer 4:3; 12:13). In these cases, the LXX renders קiץ as öк $\alpha v \theta \alpha$ instead of $\sigma \kappa o ́ \lambda o \psi$. It literally means a thornbush, the whole plant 
with thorns. But, as seen, $\alpha \kappa \kappa \nu \theta \alpha$ can also be used to refer to Isra-

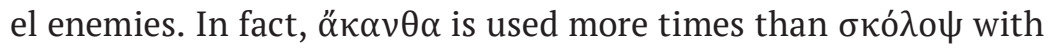
this purpose. It is possible, therefore, that the use of $\sigma \kappa o ́ \lambda о \psi$ in LXX hadn't a theological specific purpose different from " $\alpha \kappa \alpha v \theta \alpha$.

2) As explained below, $\sigma \kappa o ́ \lambda o \psi$ may function as an opponent to a spiritual privilege: the capture in paradise. If it was the case, the opposition could be triple: the capture is a divine, spiritual and unidentifiable experience. The thorn is a satanic, physical and identifiable one.

3) The $\sigma \kappa o ́ \lambda o \psi$ is attributed by Paul to the devil, and his action is described with the verb ко $\lambda \alpha \varphi$ í $\omega$, which always refers to a physical beating.

4) If Paul's enemies were the thorn, it does not appear to lend itself to a thrice-repeated prayer for its removal, nor it to be "from me" (verse 8) (Brown 2007), nor to finally giving up praying for them as a spiritual lesson. The thorn seems to be something that persists, and that Paul has somehow accepted because of a message that he claims comes from Christ. It is difficult that Paul thought that Jesus didn't want him praying for his enemies. In fact, he did the opposite (2 Tim 4:14).

5) If the thorn are Paul's enemies, it is more difficult to put together all the data that directly or indirectly seem related and that are described in this article, like bad physical presence, weakness, the satanic influence and other data that appear in Acts, Gal, and 1-2 Cor.

Several reasons support the physical nature of the thorn: 1) its location "in the flesh"; 2) its literary function as an opponent of a purely mystical experience; 3) its attribution to Satan; 4) its relationship with the concept of weakness; 5) the lack of description of the nature of the thorn would support that the Corinthians knew what it was, and that, in turn, is best explained if the thorn was something physical; 6) its complementarity with other clinical data in the life of Saint Paul.

Since Irenaeus (Adversus Haereses 1994, 5.2.3; 5.3.1) and Tertullian (De Pudicitia 13.15 1954), the majority of authors have suggested that the thorn was some type of physical ailment (Windisch 1924, 385-388) 
(A. Y. Collins 2011, 165-183) (Wenham 1980, 82). However, there is no evidence suggesting a concrete diagnosis, even in iconographic and non biblical fonts such as the Acta Pauli et Theclae, which describe Paul's physical appearance (short stature, bald head, dark eyes, eyebrows that met, aquiline nose, high forehead) (Grant 1982, 1-4).

The first thing said by Paul about the thorn is its location. Hugues (Hugues 1962, 448) Martin (Martin 2014, 1456) and Jewett (Jewett 1971,

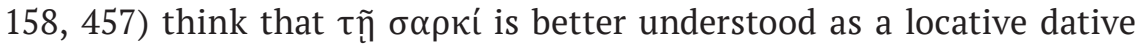
("in" the flesh). Otherwise, the thorn would have been located in (or related) to the $\pi v \varepsilon \tilde{v} \mu \alpha$ or the $\psi v \chi \eta$, or would have been contrasted with some reference to the Spirit.

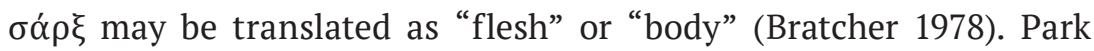
thinks that it always has a physical dimension (Park 1980). It could have a negative hue compared with $\sigma \tilde{\omega} \mu \alpha$ (Dunn 1997, 62-70). Abernathy thinks that $\sigma \alpha \alpha \rho \xi$ reflects a "fleshly inclination to do ministry man's way for man's glory". He examines the use of $\sigma \alpha \alpha \rho \xi$ in 2 Cor, noting that it indicates the physical body in 4:11 and 8:1 and a pejorative sense of "carnal" in $1: 12,17 ; 5: 16 ; 10: 2-3$ and $11: 18$. Therefore, $\sigma \alpha ́ \rho \xi$ does not denote the body absolutely, but according to its sinfulness (i.e. Gal 5:17). The same could be said about the hebrew concept basar (꼬ำ), which refers also always to the whole man, never excluding his physical dimension.

We should note that the "place" where is the $\sigma \kappa o ́ \lambda о \psi$ ( $\tau \tilde{n} \sigma \alpha \rho \kappa i ́)$ may function as a literary opponent to the location of the ecstasy which be-

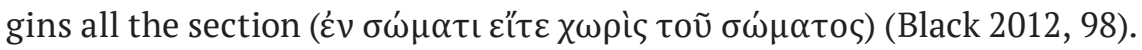
Paul contrasts his divine experience in third heaven / paradise (v.2 and 4) with the thorn, which is a satanic one (Martin 2014, 1411). Paul could boast about the first, glorious and heavenly episode, but instead of it, he boasts of an opposite and humiliating one. Paul affirms twice that he doesn't know if the heavenly experience was in the body or out of it. On the contrary, there is no doubt about where the $\sigma \kappa o ́ \lambda o \psi$ is hurting. It strikes "in the flesh". Had been the $\sigma \kappa o ́ \lambda o \psi$ a spiritual injury, Paul would have not built such a contrasting parallelism. 
The second description of the thorn is the apposition $\alpha^{\prime \prime} \gamma \gamma \varepsilon \lambda o \varsigma \sum \alpha \tau \alpha \nu \tilde{\alpha}$, used whithout any comparative particle to indicate that the $\sigma \kappa o ́ \lambda o \psi$ is "like" an angel of Satan.

Abernathy has outlined that it is difficult to explain a metaphor (the pain of the thorn) with another metaphor (Satan's Angel). For him, the $\not \alpha \gamma \gamma \varepsilon \lambda$ o $\Sigma \alpha \tau \alpha \nu \tilde{\alpha}$ is not a metaphor, but something real for Paul, the concrete referent of $\sigma \kappa o ́ \lambda о \psi$ and its causal agent. Abernathy's proposal is to

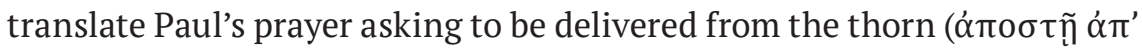
$\varepsilon \dot{\varepsilon} \mu \tilde{\text { v }) ~ a s ~ a ~ p r a y e r ~ a s k i n g ~ t o ~ b e ~ d e l i v e r e d ~ f r o m ~ S a t a n: ~ " t h a t ~ h e ~ d e p a r t s ~ f r o m ~}$ me" (Abernathy 2001).

As a biblical scholar, Paul was imbued with biblical thought about Satan's power of inflicting grievous physical damage (Job 2:1-10; 1 Cor.5:5; 1 Tim. 1:20; Lk 13:16), in addition to his work of moral seduction (Wenham 1980, 82). Gundry stated that its consideration as a 'messenger of Satan' could be an allusion to Satan's work on the body of Job (Gundry 1976, 143). It is noteworthy that Job's disease was a cutaneous one, instigated by Satan: "skin for skin!" (Job 2:4). A cutaneous disease, therefore, may have been the most easily identifiable with a satanic harm for jewish and early christian audiences.

The action of this satanic messenger is described with the verb $\kappa о \lambda \alpha \varphi i \zeta \omega$. It seems clear that its use is, again, metaphoric. It means always a physical, repetitive beating with the fist or the knuckles by an adversary (1 Cor 4:11; 1 Pe 2:20; Mt 26:67; Mc 14:65). The election of this verb seems to reinforce the idea that the $\sigma \kappa o ́ \lambda$ $\psi$ was a painful condition that can be compared with a thorn or a stake, but also with fisticuffs. This could be related with a repetitive rather than a constant pain. The use of the present tense indicates thus an ongoing action when Paul writes his letter.

\subsection{Weakness and the thorn}

The thorn appears surrounded by many allusions to weakness, which seems extremely important for Paul's theology. These allusions are concentrated in 2 Cor 10-13, where it is used 14 times (10:10; 11:21, 29 [twice], 30; 12:5, 9a, 9b, 10a. 10b; 13:3, 4a, 4b, 9). Two thirds of the 44 times Paul 
uses the word $\alpha \sigma \theta \varepsilon \dot{v} v \varepsilon\llcorner\alpha$ or its cognates in all his letters is writing to Corinthians. "It was in the Corinthian correspondence that the Pauline idea of weakness developed" (Black 2012, 6).

We suggest that, inside this correspondence, the idea developed mainly from the thorn. In fact, Paul himself claimed that he discovered the importance of glorying in own's weaknesses not by his own rational development, but as a direct revelation from the Lord after the sufferings of the thorn.

The first of the allusions to ó $\sigma \theta \varepsilon \dot{v \varepsilon} \alpha$ in 2 Cor $10-13$ is clearly linked to some physical issue: the very presence of the body of Paul is weak (2 Cor

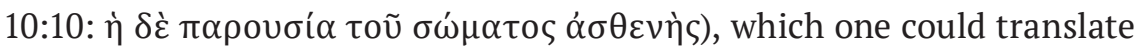
"the sick appearance of the body". We think that the use of soma here gives little space to doubt about the physical nature of this weakness.

Moreover, this ill presence might be something easily recognisable by others -as it is the case in Galatians 4:13-, and it does not seem unreasonable to assume that this weak presence has something to do with the thorn in the flesh, which is the main theological point of the section.

Being this the first time in which Paul uses the concept $\alpha \sigma \theta \varepsilon \dot{v \varepsilon \iota} \alpha$, it may be a clue for understanding some of the other re-apparitions of the term. In 11:21, the use of the plural ทं $\sigma \varepsilon v \eta \dot{\kappa} \alpha \mu \varepsilon v$ seems to refer to a common weakness with Timothy. In 11:29, the theme of weakness comes at the end of the description of Paul's life sufferings. In 11:30, $\alpha \sigma \theta \dot{v} v \varepsilon ı \alpha$ is related with the escape through a window in Damascus. In 12:5, the term functions as a first contrast with the glory of the capture in paradise. The other re-apparitions are the lesson by Jesus: "power is made perfect in weakness" (12:9a), its reception by Paul (12:9b.10a.10b), the example of Jesus himself in the cross (13:3.4a.4b) and a final rejoice on weakness (13:9).

It is interesting that there is always a physical reference used in the four groups of considerations on weakness: the presence of the body, the stoning and many other dangers during his apostolic journeys, the escape from Damascus and the crucifixion of Jesus. Paul's likeness to Christ, who was "crucified in weakness" (13:4), is better understood having both a spiritual and a physical dimension. The thorn occupies a central place in the argument, and it seems logical to refer it also to some physical substratum. 
If we accept that "Paul understands his weakness Christologically" (O'Collins 1971), we should consider that he did so largely because of the thorn. The thorn, in fact, is the main weakness of Paul, since it stands out among all other weaknesses as the only one qualified as a God's gift ( $\varepsilon \delta$ ó $\theta \eta$ ), the only one followed by a revelation and, thus, the weakness chosen by Paul to arrive at "the summit of the epistle".

Black says that 2 Cor $12: 7-10$ is the only place where Paul describes what it means to be weak-(Black 2012, 87).

All the other weaknesses converge in the thorn, since it contains the main spiritual lesson of this section of the letter, or even of the whole letter, which Paul claimed to be a revelation from Jesus: "my grace is suf-

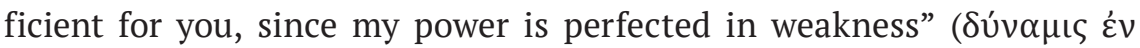
$\left.\alpha \dot{\alpha} \theta \varepsilon v \varepsilon i \alpha_{1}^{\alpha} \tau \varepsilon \lambda \varepsilon \tilde{\tau} \tau \alpha \mathrm{l}\right)$. In fact, these may be the only words of the risen Christ that we find in Pauline literature as a direct speech (1 Cor 11:23-26 are received by tradition) (O’Collins 1971).

Being so important, the lack of description of the nature of the thorn by Paul is surprising. This leads Martin to think that the nature of the thorn may have not been a mystery for Corinthians. It seems plausible that Paul would expect his readers to remember what the thorn was exactly. This is easier to think if the thorn was an ailment. Jervell suggested that Paul's enemies questioned Paul because he couldn't heal himself (Jervell 1976, 196-197) and Martin that Corinthians even "probably ridiculed Paul for his thorn" (Martin 2014, 1414).

\subsection{Medical information previous to the thorn}

We will never insist enough on the impossibility of a non speculative reconstruction of Saint Paul's medical history. However, we believe that, thinking about the thorn, we should not ignore any data that could be related to it. Specially because a basic axiom in medicine is that a single disease, and not many, is usually the best explanation for many clinical data.

These clinical data appeared long before Paul's arrival in Corinth.

His preaching in Galatia happened in 47-48 AD (Longenecker 2020, $15)$, and Paul himself states that it was possible precisely because ( $\left.\delta \iota^{\prime}\right)$ of 


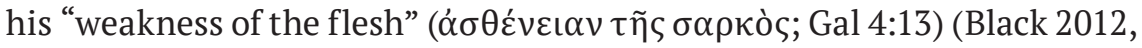
45), which could be a first allusion to a physical disease.

As we have previously showed, Paul sets the date of this capture in paradise 14 years before he wrote his second letter to the Corinthians, believed to have been written in AD 55 or 56 . If the thorn afflicted him since then (41 AD) and he was sick when he arrived in Galatia in $47 \mathrm{AD}$, it is reasonable to think that the same disease was afflicting him at one time and another. Collins thinks that this is an "illuminating assumption" (A. Y. Collins 2011, 173).

This Paul's $\alpha \sigma \theta \varepsilon \dot{v \varepsilon} \_\alpha$ is difficult to attribute exclusively to psychological or spiritual reasons.

First, $\alpha \sigma \theta \varepsilon \dot{v \varepsilon} \alpha$ can be translated as "weakness" and "frailty", but it is often used not as a moral weakness, but as a physical one. It clearly refers to an "illness" or "infirmity" in the cases of Trophimus, Timothy and Epaphroditus (2 Tim 4:20; 1 Tim 5:23; Phil 2:26-27).

Secondly, it was a weakness "of the flesh". Bodily illness is, in fact, an inherent quality of the $\sigma \alpha \dot{\alpha} \rho \xi$ (Robinson 1952, 20), which in pauline writings is not dualistically opposed to "spirit", but is used to describe the totality of man in his terrestrial condition (Cooper 1973).

Thirdly, and most important, this ó $\sigma \theta \varepsilon \dot{v \varepsilon} \alpha$ that affected Paul implied some difficulty to his audience that may have provoked rejection: "my

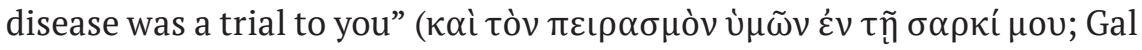

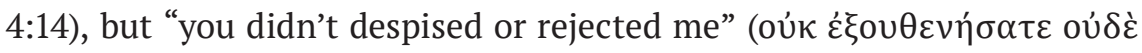
$\varepsilon \dot{\xi} \xi \varepsilon \tau \tau \dot{\sigma} \sigma \alpha \tau \varepsilon)$. Ellicott's commentary says that the last sentence "is used for the expression of physical disgust" (Ellicott's 2021).

It is also interesting to notice that the relationship between Paul and Luke began just a bit later -if we accept the unity between the letters and Acts-, and it could have some medical implications. Paul could have

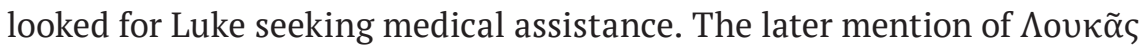
as "my beloved physician" in Col 4:14 indicates, at least, that Paul identified one of his followers, called Luke, as his physician. It is believed that this was the same Luke that accompanied Paul from Troas, and that they may knew each other since Paul's stage in Antioch after his conversion. 
One can speculate that, just after his stage in Galatia "in weakness", Paul met Luke in Troas - at least as one between other reasons- because he was looking for medical help. From this moment, Luke left Troas and joined Paul and his group, beginning of the so called "we section" of Acts 16:6-10.

In the same letter to galatians, Paul reports on "the marks of Jesus" (Gal 6:17). These marks has been described as "eschatological marks, opposed to circumcision" (Dunne 2018). More probably, they are a reference to Paul scars received as a result of persecution, since they are "on the body" (Biol 2018, 114). (Dunne 2018). The temporal reference ("from now on") is in clear contrast with the former $\alpha \sigma \theta \varepsilon \dot{v \varepsilon} \alpha$, alluded by Paul as an old and well-known issue, as the reason that caused his preaching in Galatia.

In any case, Paul has included many explicit data about his health in his letters that don't appear at all, or in a very cryptic way, in "his doctor's" book of Acts. As a conjecture, one could think that this technique reminds the physician's effort to maintain the professional secret about his patients' diagnosis (it is part of the hippocratic oath).

After preaching in Galatia and being in Troas, Paul visited other communities in Greece and finally arrived at Corinth. One can assume that he continued being a "bodily trial" for others during this period, since when he wrote much later his letters to corinthians, he manifested again a clear conscience of his bad appearance in the moment of his stage with them. Paul seems to know that his $\alpha \sigma \theta \varepsilon \dot{v} \varepsilon\llcorner\alpha$ was remembered by the readers of the letter, and it was related with his very own physical appearance:

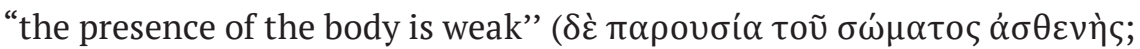
2 Cor 10:10). Here, "weakness" is applied to $\sigma \omega ́ \mu \alpha$, so it has a physical dimension which could be related with the "thorn in the flesh". Thrall suggests that it could be the same affliction because of the danger of death mentioned in the beginning of the letter (2 Cor 1:8) (Thrall 1994, 219).

On the other hand, Paul's stage in Corint finished abruptly after one year and a half, shaving his head and making a vow in Cenchreas seaport (Acts 18:18). It is believed that this vow was the naziriate. The specific reason to do so is not said in the book of Acts, but there is good evidence 
that in the first century it was common to become a nazirite as a supplication to God for the cure of a disease. Paul himself wrote later that precisely in Cenchreas he needed "a succorer", Pheobe (Rm 16:1-2). We cannot know which kind of help Pheobe provided to Paul, but the geographical and chronological coincidence deserves to be mentioned.

All the data provided fits well with the following chronological sequence: a possible disease affecting Paul that is a trial for them and could provoke rejection to the church in Galatia. This disease could be the reason for the care of Luke the physician in Troas and, after more than one year sick in Corinth, a possible nazirite vow seeking for health. If the thorn was a disease, this vow may be one of the three times he asked God to make it disappear (2 Cor 12:8), though number "three" is here symbolic for many authors (Martin 2014, 1464-1465).

The Nazirite vow appears several times in the Bible (cfr. Nm 6:1; Judg 13:2; 1 Sam 1:11; 1 Mac 3:49; Lk 1:15). Josephus explains how votaries were typically perceived in the first century AD (A.J. 4.72; 5.344-7; 19.294). According to him, but also to Philo and the Tosefta, the vow was a sort of making oneself a type of first fruit offering, mostly in Pentecost, acquiring a state of holiness.

We retain some cases in which the reason to become a nazirite is explained. Helena of Adiabene made the nazirite vow for the safe return from the war of his son ( $m$. Naz. 3.6). Miriam of Tadmor, for his daughter in danger ( $m$. Naz. 6. 11). Berenice, sister of Agrippa II, in 66 AD, despite the peril of her life because of the riots, she "was visiting Jerusalem, to discharge a vow to God; for it is customary for those suffering from illness and other affliction to make a vow to abstain from wine and to shave their heads" (Bellum Judaicum 2.313-4) (Chepey 2015, 57-63).

In all mentioned cases, the nazirite vow implies a request to God to be free of some physical danger. Therefore, it is possible that Paul became a nazirite hoping for the healing of the disease he called later "thorn in the flesh".

If this was the case, the nazirite vow could explain why Paul, just after leaving Corinth, seems so decided not to stay at Ephesus, despite the repeated demands he received. He may have wanted to arrive soon in Jeru- 
salem, before Pentecost. Vowers had 30 days-time to offer his hair shorn in the Temple and fulfil the vow (Acts 8:20).

\section{Differential diagnosis}

If we assemble the information obtained from the books of Acts, Galatians and Corinthians, the set of displayed data would seem to suggest that Paul's thorn in the flesh could have been a chronic disease, beginning in 41-47 AD and that could last at least until $58 \mathrm{AD}$ (when Paul states in 2 Cor that he prayed to be free from the $\sigma \kappa o ́ \lambda$ o $\psi$ without success).

If Paul was sick, it is easier to think that he suffered a chronic disease with long relapses and short flares, without severe or even progressive global deterioration, that would permit travelling thousands of kilometres during years, preaching and working (Hubbard 2002, 386). It should cause pain like thorns or/and be comparable with a blow with the fist, and a physical appearance that could cause detestation. It would be easily recognised by a first century jew as a satanic harm.

Flagellation, lapidation and shipwrecks (Acts 14:19; 16:22; 2 Cor 11:23) may have produced scars or bone fractures to Paul, but the vast majority of these trauma occurred after the 41-47 period.

Other diseases suggested by several authors can be ruled out because, remaining untreated, would have led to a very considerable deterioration that wouldn't permit Paul's work: rheumatoid arthritis, mycetoma (Fahal 2004), or even epilepsy (Vercelleto 1994) (Landsborough 1987).

Epilepsy has been suggested by many authors, not only to explain the thorn, but also to give a naturalistic explanation of Paul's experience with Christ. It is difficult to assign to epilepsy what Paul says about his $\pi \alpha \rho o v \sigma i \alpha$ and $\alpha \sigma \theta \varepsilon \dot{v \varepsilon} \alpha$. Moreover, epilepsy is not clearly painful like a thorn, since the patient remains unconscious during the crisis. Finally, in ancient times epileptics were suspicious of satanic possession. Had Paul been epileptic, he could have been exorcised by other christians, but not sent by the church as an apostle.

Malaria seems to cover all Paul's symptoms for Ramsay, who also considered the data found in the letter to Galatians (Ramsay 1898, 94-97). 
However, we can rule out Plasmodium Falciparum malaria because of its potential severe or fatal early complications, and its rare recrudescences after a year. $P$. Ovale, $P$. Vivax and $P$. Malariae may produce several relapses over years, and could account for a relapsing and not severe disease (Garcia 2010). However, its consequences on physical appearance are not clear. Moreover, there is no biblical basis for attributing malarial fever to Satan. Paul the pharisee, the biblical scholar, must have had scriptural reasons to state that his thorn had been directly produced by Satan.

Cephalea has also been proposed as a candidate to be the $\sigma \kappa o ́ \lambda o \psi$ (Tertullianus 1954). However, it has always been a common and well-known disease, not humiliating nor affecting clearly physical appearance, and never related to Satan in the Bible.

Bullock and other authors have proposed that a lightning strike in the moment when Paul was struck blind could be the beginning of some ophthalmologic problems and the $\sigma \kappa o ́ \lambda о \psi$ (Bullock 1994). This would explain why Paul seems not to see the high priest during his trial before the Sanhedrin (Acts 23, 5) and other expressions in galatians: "if you could have done so, you would have torn out your eyes and given them to me" (Gal 4:15), and the "large letters" at the end of the letter ( $\pi \eta \lambda$ íко $\gamma \rho \alpha ́ \mu \mu \alpha \sigma \mathrm{v}$; Gal 6:11) (Manchester 1972). In spite of this, an ophthalmologic disease is hard to reconcile with Paul's intended healing after his conversion. Moreover, the expression in Gal 4:15 was common in antiquity, meaning the predisposition to any sacrifice for someone (i.e. Deut 32:10; Ps 17:8; Prov 7:2; Zech 2:8; Horace, Sat II 5:33) (Eadie 1869, 327). An ocular disease doesn't fit well with Paul's enormous apostolic activity, there are no biblical reasons to compare it with a Satan's angel, and an association with bad physical appearance is not obvious.

Similar reasons seem to discard other conditions proposed in the past, like a "defect of speech" (10:1, 9-11; 11:6) (Mangan 1943), otalgia and otological diseases (Knapp 1916). Otitis media could account for several episodes of acute pain, but not for the rest of explained data.

Cutaneous diseases are the most obvious candidates to affect physical appearance and, because of Job's case, to be attributable to Satan. Some 
of them can be associated with asthenia, pain and long duration without global deterioration, and would have allowed Pauls's tasks.

Some diseases with prominent cutaneous manifestations could account for all the mentioned aspects related with the $\sigma \kappa o ́ \lambda о \psi$. Lupus erythematosus and dermatomyositis can present with a low number of flares in many years. These diseases could respond to the bad presence, weakness and pain that Paul refers to. Those diseases may produce cutaneous rash, photosensitivity, arthritis and asthenia. Lupus may also include other clinical features suggested by other authors, such as cephalea, epilepsia and ophthalmologic lesions, and even ophtalmological and neurological manifestations including deafness. Lupus can also manifest as painful subcutaneous nodules (panniculitis).

There is a strong argument against many cutaneous diseases as candidates for Paul's thorn. Most patients who would have been diagnosed in our days of lupus or dermatomyositis would have been diagnosed as lepers in the first century. The same can be said of bullous diseases, skin cancer, psoriasis, lichen planus, ulcus rodens or a suppurative strange body. Leprosy diagnosis would suppose legal impurity, and, in the case of Paul, it would have made impossible his mission. Some of these diseases are not usually painful, some others would not have been compared with a thorn or/and wouldn't have permitted Paul's activity over years.

Angioedema and/or urticaria, by the contrary, cannot be confused with leprosy because of the evanescence of the cutaneous lesions. Chronic urticaria is an autoimmune disease. It presents with highly itchy weals. In some cases, there is also deep swelling of the skin, which is known as angio-oedema. Some patients have only episodes of pure angio-oedema, which are painful and relapsing. Urticaria and/or angio-oedema have no direct effect on general health, but are very distressing because of the itching, pain and disfigured appearance that can lead to problems in social relationships. Many cases have an unpredictable number of flares during several years, and then resolve spontaneously.

Recurrent herpes, leukocytoclastic vasculitis, nodular vasculitis and panniculitis do not have evanescent lesions, but in some cases the $\mathrm{cu}-$ taneous signs disappear in days or weeks after each flare. This could be 
enough to distinguish it from leprosy in the first century AD. These diseases can produce severe pain, which could be described by the patient as a thorn.

\section{Conclusions}

We do not know the exact meaning of the "thorn in the flesh", but we do know that is was fundamental for the development of Paul's theology, a historical figure which had an unparalleled influence in the first millennium for western civilisation (Wright 2018, XII). The thorn remains as an icon of the significance of humility for christianity. Weakness brings grace to completion ( $\tau \varepsilon \lambda \varepsilon i ́ \omega \sigma \iota \varsigma)$ (Martin 2014, 1468).

The thorn is probably a metaphorical reference to a painful disease which Paul thought was inflicted to him non-metaphorically by Satan, by which Paul could have felt ashamed.

A cutaneous disease would explain many data in Paul's life and thought. If Paul suffered a cutaneous disease with a chronic course and relatively brief relapses, there would be one simple reason that would reach to explain a possible rejection by galatians and corinthians, the belief in a satanic origin of the disease -like Job's one-, Paul's weakness, bad appearance, a pain like a thorn or a buffet, his continuous work in apostolic tasks for years, the nazirite vow and the help of Phoebe in Cenchreas. Most important, this sort of disease would keep him from glorying in anything

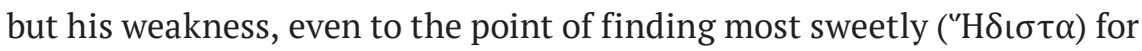
him and for benefit of others (13:9).

Other diseases may account to some of the clinical data we have previously discussed, but we have tried to show that skin conditions merit to be included as a possibility.

The aetiology of Paul's thorn cannot be known with certainty, but we think that cutaneous diseases like lupus erythematosus, angio-edema, panniculitis, vasculitis or herpes should be added to the list of candidates to be Saint Paul's "thorn in the flesh". 


\section{References}

à Lapide, Cornelius. 1908. The Great Commentary of Cornelius à Lapide: II Corinthians and Galathians (1567-1637). Edinburgh: J Grant.

Abernathy, David. 2001. "Paul's thorn in the flesh: a messenger of Satan?” Neotestamentica 35: 71.

Aquinas, Saint Thomas. 1986. Super II Epistolam ad Corinthios. Traducido por Salvador Abascal. México: Tradición.

Augustine, Saint. De Natura et Gratia. 414.

Biol, Justin. 2018. Martyred for the Church: Memorializations of the Effective Deaths of Bishop Martyrs in the Second Century. Tubingen: Mohr Siebeck.

Black, David Alan. 2012. Paul, apostle of weakness. Astheneia ans its cognates in the pauline literature. Eugene : Pickwick.

Bratcher, Robert. 1978. “The meaning of sarx («flesh») in Paul's letters.” The Bible translator 29, $\mathrm{n}^{\circ}$ 2: 212-218.

Brown, Larry. 2007. “academia.edu.” academia.edu. October. https://www.academia.edu/3885721/The_Apostle_Pauls_Thorn_in_the_Flesh_2_Corinthians_12 (último acceso: 14 de 05 de 2021).

Bullock, JD. 1994. “Was Saint Paul struck blind and converted by lightning?” Survey of Ophthalmology 39, $\mathrm{n}^{\circ}$ 2: 151-160.

Chepey, Stuart. 2015. Nazirites in Late Second Temple Judaism. Leiden-Boston: Brill.

Collins, Adela Yabro. 2011. “Paul's disability.” En Disability Studies and Biblical Literature., de Candida R. Moss and Jeremy Schipper (eds), 165-183. New York: Palgrave Mac Millan.

Collins, Adela Yarbro. 2011. "Paul's disability: the thorn in the flesh.” In Disability Studies and biblical literature, by Candida Moss and Jeremy Schiper. New York: Palgrave-McMillan.

Cooper, Eugene J. 1973. “Sarx and sin in Pauline Theology.” Laval théologique et philosophique 29, $\mathrm{n}^{\circ}$ 3: 243-255.

Danker, Frederik William, and Walter Bauer. 2000. A Greek-English Lexicon of the New Testament and other early Christian literature. Electronic edition. Chicago: The University of Chicago Press.

Dunn, James D.G. 1997. The theology of Paul the Apostle. Grand Rapids / Cambridge: W.B. Eerdmans.

Dunne, John Anthony. 2018. "Eschatological Emphases.” Journal of Biblical and Theological Studies 3, $\mathrm{n}^{\circ}$ 2: 243. 
Eadie, John. 1869. A Commentary on the greek text of the epistle of Paul to the Galatians. London: T\&T Clark.

Ellicott's. 2021. BibleHub. 5 de 2021. https://biblehub.com/commentaries/galatians/4-14.htm (último acceso: 12 de may de 2021).

Fahal, A.H. 2004. "Mycetoma: a thorn in the flesh.” Transactions of The Royal Society of Tropical Medicine and Hygiene 98, n 1: 3-11.

Furnish, Victor Paul. 1984. II Corinthians. Vol. AB 32A. New York: Doubleday.

Garcia, Lynne S. 2010. “Malaria.” Clin Lab Med: 93-129.

Gooder, Paula. 2006. Only the Third Heaven? 2 Corinthians 12.1-10 and Heavenly Ascent. London: T\&T Bloomsbury.

Grant, Robert M. 1982. “The description of Paul in the Acts of Paul and Thecla.” Vigiliae Christianae: 1-4.

Gundry, Robert H. 1976. Soma in biblical theology. Cambridge: Cambridge University Press.

Hubbard, Moyer V. 2002. “2 Corinthians.” En 1 \& 2 Corinthians, de Clinton E. Arnold, 385. Grand Rapids: Zondervan.

Hugues, Philip E. 1962. Paul's Second Epistle to the Corinthians. Grand Rapids: Eerdmans.

Irenaeus. 1994. Adversus Haereses. Vol. 1, de Ante-Nicene Fathers: The apostolic fathers, Justin Martyr, Irenaeus, de Alexander Roberts and James Donaldson, editado por Alexander Roberts and James Donaldson. Peabody: Hendrickson Publishers.

Jegher-Bucher, Verena. 1997. “'Thorn in the flesh'/'Der Pfahl im Fleisch': Considerations about 2 Corinthians 12.7-10 in connection with 12.1-13.” En The Rhetorical analysis of Scripture, de Stanley E. Porter \& Thomas H. Olbricht, 388-397. Sheffield: Sheffield Academic Press.

Jervell, Jacob. 1976. “Der schwache Charismatiker.” In Rechtfertigung : Festschrift für Ernst Käsemann zum 70. Geburtstag, by Ernst Käsemann, Johannes Friedrich, Wolfgang Pöhlmann and Peter Stuhlmacher, 185-199. Tübingen: Mohr. Jewett, Robert. 1971. Paul's Anthropological Terms. Leiden: Brill.

Keener, Craig S. 2005. 1-2 Corinthians. New York: Cambridge University Press. Kittel, Gerhard, and Gerhard Friedrich. 1985. Dictionary of the New Testament. Translated by Geoffrey W. Bromiley. Grand Rapids: Eerdmans Publishing Company.

Knapp, Margaret L. 1916. “Paul the deaf.” The Journal of Religion 47, n 5: 311-317. Landsborough, D. 1987. "St Paul and temporal lobe epilepsy.” J Neurol Neurosurg Psychiatry 50, n 6: 659-665. 
Longenecker, Bruce W. 2020. The New Cambridge Companion to St. Paul. Cambridge: Cambridge University Press.

Luther, Martin. 2011. Comm on Gal 1535. Traducido por Harold Camacho. palibrio.com.

Manchester, Paul Thomas. 1972. “The blindness of Saint Paul.” Arch Ophtal 88, $n^{\circ} 2:$ 316-321.

Mangan, Edward A. 1943. "Was Saint Paul an invalid?” The Catholica Biblical Quarterly 5, n 1: 68-72.

Martin, Ralph P. 2014. 2 Corinthians. Second edition. Vol. 40. Grand Rapids: Zondervan.

McCant, Jerry W. 1988. "Paul's Thorn of Rejected Apostleship.” New Testament Studies 34: 550-572.

Mullins, Terence Y. 1957. "Paul's Thorn in the Flesh.” Journal of Biblical Literature $76, \mathrm{n}^{\circ}$ 4: 299-303.

O’Collins, Gerald G. 1971. “Power made perfect in weakness, 2 Cor 12: 9-10.” Catholic Biblical Quarterly 33.4: 528-537.

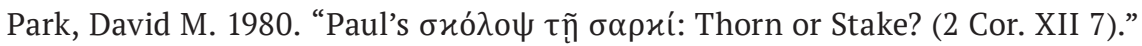
Novum Testamentum 22: 179-183.

Ramsay, William Mitchell. 1898. Saint Paul the traveller and the roman citizen. London: Hodder \& Stroughton.

Robinson, John A.T. 1952. The Body: A Study in Pauline Theology (Studies in Biblical Theology). London: SCN Press.

Tertullianus. 1954. De Pudicitia 13.15. Editado por Typographi Brepols. Brepols.

Thrall, Margaret E. 1994. A critical and exegetical commentary on the second epistle to the Corinthians. London: t\&t Clark.

Vercelleto, P. 1994. “Saint Paul disease. Ectasia and exstatic seizures.” Rev Neurol 150, no 12: 835-839.

Vincent's. 2021. “biblehub.com.” 13 de 05. https://biblehub.com/commentaries/2_corinthians/12-7.htm (último acceso: 14 de 05 de 2021).

Wenham, David. 1980. “The christian life: a life of tension? A consideration of the nature of christian experience in Paul.” In Pauline Studies. Essays presented to F.F. Bruce, by Donald Hagner and Murray Harris, 80-86. Grand Rapids: Paternoster Press.

Windisch, Hans. 1924. Der zweite Korintherbrief. Göttingen: Vandenhoeck \& Ruprecht.

Wright, Nicholas Thomas. 2018. Paul: a biography. San Francisco: HarperOne. 
